\title{
A PHASE II TRIAL EXPLORING THE EXTENSIVE INTRA-OPERATIVE PERITONEAL LAVAGE (EIPL) AS A PROPHYLACTIC STRATEGY FOR PERITONEAL RECURRENCE IN LOCALLY ADVANCED GASTRIC CANCER: reporting postoperative morbidity and mortality after early closure
}

\author{
Thales Paulo BATISTA ${ }^{1}$, Mário Rino MARTINS ${ }^{2}$, Euclides Dias MARTINS-FILHO ${ }^{3}$ and \\ Rogerio Luiz dos SANTOS²
}

\begin{abstract}
Background - The Extensive Intraoperative Peritoneal Lavage (EIPL) has been proposed as a practical prophylactic strategy to decrease the risk of peritoneal metastasis in gastric cancer. Objective - To explore the safety and efficacy of the EIPL in our locally advanced gastric cancer patients. Methods - This study is an open-label, double-center, single-arm phase II clinical trial developed at two tertiary hospitals from Recife (Pernambuco, Brazil). Results - The study protocol was prematurely closed due to slow accrual after only 16 patients had been recruited to participate. Eight of them were excluded of the protocol study during the laparotomy, whereas four cases were also excluded from the per-protocol analysis. Two patients had died in hospital before 30 days and six were alive with no evidence of cancer relapses after a follow-up ranging from five to 14,2 months (median of 10.6 months). In the intention-to-treat analysis, three of eight patients suffered of gastrointestinal leakages and two of them had died. On a per-protocol basis, two of four patients presented this type of postoperative complication and one of them had died. All deaths occurred as a somewhat consequence of gastrointestinal leakages. Conclusion - We could not make any conclusion about the safety and efficacy of the EIPL, but the possibility of this approach might increase the rate of gastrointestinal leakage is highlighted.
\end{abstract}

HEADINGS - Stomach neoplasms. Lymph node excision. Local neoplasm recurrence.

\section{INTRODUCTION}

Radical surgery remains a cornerstone in the management of patients with resectable locally advanced disease, whereas efforts to reduce its high mortality rates are currently focused in an multidisciplinary management. In order to contribute for decreasing recurrence rates, surgeon's attention usually first turns to the extent of lymph node dissection and radicality of surgery. However, the lymph node dissection and surgical manouvers proved to be a main factor for spreading viable free cancer cells into the peritoneal cavity and itselves appears to play a role for peritoneal dissemination and recurrence of gastric cancer( ${ }^{(3)}$.

The most of gastric adenocarcinomas will eventually spread to the peritoneum sooner or later in their natural history as result of intra-peritoneal free cancer cells released from the serosal surface of the primary site and/or from lymphatic channels opened during the lymph node dissection. In these settings, an extensive peritoneal washing might flush out the free cancer cells in the peritoneal cavity and has been proposed as a practical approach to decrease the risk of peritoneal metastasis ${ }^{(1,3)}$. Applying this formidable method for reducing the number of free cancer cells to potentially zero, namely Extensive Intraoperative Peritoneal Lavage (EIPL), a remarkably better prognosis has been shown for Asian patients suffering of gastric cancer ${ }^{(2,4,5)}$. Based on the promising results of pioneering studies, we explored this prophylactic strategy for preventing relapses in our locally advanced gastric cancer patients from Northeast Brazil.

Department of Surgery/Oncology, Faculdade Pernambucana de Saúde, Instituto de Medicina Integral Professor Fernando Figueira (FPS/IMIP); ${ }^{2}$ Department of Abdominal Surgery, Hospital de Câncer de Pernambuco (HCP); ${ }^{3}$ Department of General Surgery, FPS/IMIP, Recife, PE, Brasil.

Correspondence: Prof. Thales Paulo Batista. Rua Pio IX, 435. Ed. Maria Raquel, ap. 701. Madalena - CEP: 51710-260 - Recife, PE, Brasil. E-mail: t.paulo@bol.com.br 


\section{METHODS}

This study is an open-label, double-center, single-arm clinical trial on safety and efficacy exploring the adoption of the EIPL as a practical prophylactic strategy for peritoneal recurrence in patients with locally advanced gastric cancer. The protocol was reviewed by the Ethics Research Committees of our institutions (CAAE: 04016212.5.0000.5201), and was also registered at the ReBEC - Registro Brasileiro de Ensaios Clínicos as UTN: U1111-1133-7610 (REQ: 865). All procedures complied with the standards of the Declaration of Helsinki and current Brazilian ethical guidelines.

The primary endpoint of this study was the overall 2-year recurrence rate. The secondary endpoints were the site of the first recurrence, the surgical morbidity according to the Clavien-Dindo classification, and the overall and disease-free survival. The inclusion criteria are as follows: patients candidates for elective radical gastrectomy; histologically proven adenocarcinoma of the stomach clinically staged as T3-4 or $\mathrm{N}+$ (TNM 7th edition); radiological no evidence of distant metastasis; aged 18 to 75 years; performance status (Eastern Cooperative Oncology Group) 0 to 2; previous no treatment with radiotherapy, chemotherapy or major abdominal surgery; adequate organ function (cardio-respiratory, hepato-renal and haematological); and written informed consent. The exclusion criteria included apparent or confirmed infections; limiting comorbidities; others active malignant neoplasms; neuropsychiatric disorders; antecedents of drug allergies, and pregnant or breastfeeding; patients with unresectable disease (candidates for non-curative surgery) or unsuspected metastatis discovered at the time of surgery; patients with tumors classified as pT1-2 without lymph node metastasis, positive margins or less than 15 lymph nodes reported in the postoperative pathological exam; and positive staging peritoneal cytology.
In summary, after the main surgical procedure (gastrectomy), the peritoneal cavity was extensively rinsed 10 times with 1 liter of physiological saline at a time, followed by complete aspiration of the fluid - the approach named Extensive Intra-operative Peritoneal Lavage (EIPL). To ensure an $80 \%$ power to detect a reduction of half of the cancer relapses ${ }^{(1-5)}$ under a one-sided alpha of $5 \%$, the planned sample size was 30 cases. Herein, we assumed a hypothetical recurrence rate of about $55 \%$ and a maximum follow-up loss of $20 \%$, also supposing that almost all of these relapses would occur in the first 2 years after surgery. For safety monitoring, an interim analysis was scheduled for when half of the patients had been recruited. After treatment, patients were periodically followed up with physical examination, lab tests, imaging exams, and upper endoscopy, as appropriated.

\section{RESULTS}

The study protocol had been opened from January 2013 to September 2014 but was prematurely closed due to slow accrual after only 16 patients had been recruited to participate. Eight of them were excluded of the protocol study during the laparotomy due to evidence of peritoneal carcinomatosis $(n=6)$ or irresacability $(n=2)$. Data from eight eligible patients who underwent EIPL immediately after the gastrectomy procedures were analyzed on an intention-to-treat basis, whereas four cases were excluded from the per-protocol analysis because of were pT1N0 tumors treated with D1 gastrectomy $(n=2)$, presented pM1 disease - ususpected metastasis in the hipofaginge discovered at the time of surgery $(n=1)$, or had a involved distal margim $(n=1)$ on the postoperative pathological exam. The summary of their baseline characteristics is presented in the Table 1.

TABLE 1. Baseline characteristics of patients who underwent EIPL immediately after the gastrectomy

\begin{tabular}{|c|c|c|c|c|c|c|c|c|}
\hline Variable & Case 1 & Case 2 & Case 3 & Case 4 & Case 5 & Case 6 & Case 7 & Case 8 \\
\hline Age (years) & 41 & 45 & 66 & 45 & 67 & 73 & 67 & 50 \\
\hline Gender & Male & Female & Male & Female & Male & Male & Male & Female \\
\hline $\begin{array}{l}\text { Performance } \\
\text { Status }^{1}\end{array}$ & 1 & 1 & 1 & 1 & 1 & 1 & 2 & 1 \\
\hline $\mathrm{ASA}^{2}$ & 1 & 1 & 1 & 1 & 2 & 2 & 2 & 2 \\
\hline $\begin{array}{l}\text { Borrmann } \\
\text { Type }\end{array}$ & IV & III & III & I & II & III & III & III \\
\hline Site of tumor & Whole (LMU) & Lower (L) & Lower (L) & Lower $(\mathrm{L})$ & Middle (M) & Middle (M) & Middle (M) & Lower (L) \\
\hline $\begin{array}{l}\text { Type of } \\
\text { Gastrectomy }\end{array}$ & Total & Subtotal & Subtotal & Total & Total & Total & Total & Subtotal \\
\hline $\begin{array}{l}\text { Histology } \\
\text { (WHO) }\end{array}$ & Papillary & Tubular & $\begin{array}{l}\text { Signet-ring } \\
\text { cell }\end{array}$ & Mucinous & $\begin{array}{l}\text { Signet-ring } \\
\text { cell }\end{array}$ & Papillary & Papillary & Mucinous \\
\hline $\begin{array}{l}\text { Histological } \\
\text { Grade }\end{array}$ & G1 & G2 & $\mathrm{G} 3 / 4$ & NR3 & $\mathrm{G} 3 / 4$ & G2 & G1 & $\mathrm{G} 3 / 4$ \\
\hline $\begin{array}{l}\text { UICC pT- } \\
\text { Stage }\end{array}$ & T4a & $\mathrm{T} 4 \mathrm{a}$ & T3 & T1a & T1b & T4a & T4a & T4a \\
\hline $\begin{array}{l}\text { UICC pN- } \\
\text { Stage }\end{array}$ & No & $\mathrm{N} 2$ & No & No & No & N1 & N1 & N1 \\
\hline
\end{tabular}

\begin{tabular}{lllllll}
$\begin{array}{l}\text { Type of } \\
\text { Adjuvancy }\end{array} \quad$ Chemoterapy & Chemoradiation & None $^{4}$ & None & None & Chemoradiation & None \\
\hline
\end{tabular}

${ }^{1}$ Eastern Cooperative Oncology Group (ECOG) classification system; ${ }^{2}$ American Society of Anesthesiologists (ASA) physical status classification system; ${ }^{3}$ NR: Not reported; ${ }^{4}$ This patient died before discharge the hospital. 
Table 2 summarizes the operative complications. Two patients had died in hospital before 30 days and six were alive with no evidence of cancer relapses after a follow-up ranging from five to 14.2 months (median of 12.9 months). In the intention-to-treat analisys, three of eight patients suffered of gastrointestinal leakages and two of them had died. On a per-protocol basis, two of four patients presented this postoperative complication and one of them had died. All of these deaths occurred as a somewhat consequence of gastrointestinal leakages. Among those patients who underwent adjuvant therapies, none of them completed the treatment as planed after a total gastrectomy.

\section{DISCUSSION}

By far, the most likely cause of peritoneal dissemination is the presence of intra-peritoneal free cancer cells released from serosal surface of the primary site. However, exploring the mechanisms of peritoneal recurrence in gastric cancer by an ultra-rapid quantitative RT-PCR system, Marutsuka and colleagues $^{(3)}$ clearly revealed the existence of free cancer cells in the peritoneal cavity after lymphadenectomy, even when the gastric serosa was not disrupted. Accordingly, using cytological analysis by cell smearing and immunohistochemistry to detect disseminated cancer cells after D2 gastrectomy, $\mathrm{Yu}$ et al. ${ }^{(5)}$ also demonstred that lymphadenectomy can disseminate cancer cells into the abdominal cavidity, which leads to increased risk of peritoneal metastasis. These very important data may explain the high rates of peritoneal recurrence after curative operations, despite neither the apparent existence of abdominal free cancer cells nor overt peritoneal metastasis before surgery.

Fortunately, based on the law of "limited diluition", Shimada et al. ${ }^{(4)}$ and Marutsuka et al. ${ }^{(3)}$ also developed a quite formidable method for reducing the number of free cancer cells into the abdomen to potentially zero, namely by EIPL. According to their pioneering studies that far exceeded any expectations and showed a remarkably better prognosis for patients suffering of advanced gastric cancer $(\mathrm{C} 1 \mathrm{P} 0)^{(2,4)}$, these authors have strongly advocated the adoption of EIPL therapy for patients with positive peritoneal washing cytology with no overt peritoneal carcinomatosis, and for all patients with serosa-involved gastric cancer or lymph node metastases, regardless of their cytological status ${ }^{(1,3)}$. In these settings,
Yu et al ${ }^{(5)}$ similarly presented the potential value of EIPL for decreasing the risk of peritoneal metastasis in patients with locally advanced stages who underwent D2-gastrectomies, and a randomized phase III trial (CCOG 1102) exploring the prognostic value of EIPL in addition to standard treatment for resectable advanced gastric cancer has started in Japan (UMIN Clinical Trials Registry: UMIN000005907).

The innovative EIPL method is simple, very little time-consuming, and inexpensive. Similarly, it is not curtailed by place or time, and does not need any special techniques or devices in order to be applied. However, there is a lack of reporting its potential postoperative complications ${ }^{(2,4,5)}$ and thus, we considered important to present our experience with the use of this surgical strategy in non-Asian patients. Despite the study has been prematurely closed, it was the first aimed to explore the EIPL approach in Brazil. As main explanations to poor accrual, we would like to point the trend of avoiding upfront surgery for locally advanced stages in favor to the use of perioperative chemotherapy, and the difficulties of involving surgeons in clinical studies that require some changes in their surgical practice. In these settings, we could not make any conclusion about the safety and efficacy of the EIPL, but the possibility of this approach might increase the rate of gastrointestinal leakage is highlighted. We are currently eagerly waiting for the results of the Japonese CCOG 1102 phase III trial.

\section{ACKNOWLEDGMENTS}

The authors would like to thanks the following surgeons for their contribution to data collection: Dr. Tarcísio Dias, Dr. Flávio Kreimer, Dr. Roberto Lustosa, Dr. Vandré Carneiro, Dr. Cristiano Souza Leão, and Dra. Christine Miranda.

\section{Authors' contributions}

Study concept and design: Batista TP and Martins MR. Acquisition of data: all authors, mainly Martins MR, Martins-Filho ED and Santos RL. Analysis and interpretation of data: all authors, mainly Batista TP and Martins MR. Drafting of the manuscript: Batista TP. Critical revision of the manuscript for important intellectual content: all authors. Descriptive (statistical) analysis: Batista TP. Material support: all authors, mainly Batista TP. Study supervision: Batista TP and Martins MR.

TABLE 2. Summary of complications after the gastrectomy plus EIPL, according to the Clavien-Dindo classification

\begin{tabular}{cccl}
\hline Cases & Total & Higher Grade & Description \\
\hline $\mathrm{n}^{\circ} 1$ & 1 & IIIB & Duodenal stump leakage requiring re-laparotomy \\
$\mathrm{n}^{\circ} 2$ & 0 & - & - \\
$\mathrm{n}^{\circ} 3$ & 2 & $\mathrm{~V}$ & Gastrojejunal anastomotic leakage requiring re-laparotomy, and fatal pulmonary embolism \\
$\mathrm{n}^{\circ} 4$ & 1 & $\mathrm{I}$ & Wound infection treated by opening at the bedside \\
$\mathrm{n}^{\circ} 5$ & 0 & - & - \\
$\mathrm{n}^{\circ} 6$ & 0 & - & - \\
$\mathrm{n}^{\circ} 7$ & 2 & $\mathrm{~V}$ & $\begin{array}{l}\text { Tachyarrhythmia requiring adenosine, and jejunojejunal anastomotic leakage requiring re-laparotomy; } \\
\text { death by sepsis }\end{array}$ \\
$\mathrm{n}^{\circ} 8$ & 1 & $\mathrm{I}$ & Postoperative paralytic ileus requiring prokinetics \\
\hline
\end{tabular}


Batista TP, Martins MR, Martins-Filho ED, Santos RL. Ensaio clínico de fase II avaliando a lavagem peritoneal intraoperatória extensiva como estratégia profilática para a recidiva peritoneal no câncer gástrico localmente avançado: relato da mortalidade e morbidade pós-operatória após encerramento prematuro do estudo. Arq Gastroenterol. 2015,52(2):161-4.

RESUMO - Contexto - A lavagem peritoneal intra-operatória extensiva (EIPL) tem sido proposta como uma estratégia profilática para diminuir o risco de disseminação peritoneal no câncer gástrico. Objetivo - Explorar a segurança e eficácia da EIPL em nossos pacientes com câncer gástrico localmente avançado. Métodos - Realizou-se ensaio clínico de fase 2 e braço único, aberto e multicêntrico em dois Hospitais terciários de Recife (Pernambuco, Brasil). Resultados - O protocolo do estudo foi fechado prematuramente devido ao lento recrutamento quando apenas 16 pacientes haviam sido recrutados. Oito deles foram excluídos do estudo durante a laparotomia, enquanto outros quatro casos também foram excluídos da análise per protocolo. Dois pacientes morreram no hospital antes de 30 dias e seis estavam vivos sem evidência de recidiva após proservação que variou de 5 a 14,2 meses (mediana de 10,6 meses). Na análise de intenção de tratar, três dos oito pacientes apresentaram fístulas gastrointestinais e dois deles morreram. Na análise per protocolo, dois dos quatro pacientes apresentaram este tipo de complicação pós-operatória e um deles morreu. Todos os óbitos ocorreram como consequência da ocorrência de fístulas gastrointestinais. Conclusão - Não se pôde concluir sobre a segurança e eficácia do EIPL, mas a possibilidade de que esta abordagem aumente as taxas de fístulas gastrointestinais deve ser considerada.

DESCRITORES - Neoplasias gástricas. Excisão de linfonodo. Recidiva local de neoplasia.

\section{REFERENCES}

1. Kuramoto M, Shimada S, Ikeshima S, Matsuo A, Kuhara H, Eto K, Baba H. A proposal of a practical and optimal prophylactic strategy for peritoneal recurrence. J Oncol. 2012;2012:340380.

2. Kuramoto M, Shimada S, Ikeshima S, Matsuo A, Yagi Y, Matsuda M, Yonemura Y, Baba H. Extensive intraoperative peritoneal lavage as a standard prophylactic strategy for peritoneal recurrence in patients with gastric carcinoma. Ann Surg. 2009;250(2):242-6
3. Marutsuka T, Shimada S, Shiomori K, Hayashi N, Yagi Y, Yamane T, Ogawa M. Mechanisms of peritoneal metastasis after operation for non-serosa-invasive gastric carcinoma: an ultrarapid detection system for intraperitoneal free cancer cells and a prophylactic strategy for peritoneal metastasis. Clin Cancer Res. 2003;9(2):678-85.

4. Shimada S, Tanaka E, Marutsuka T, Honmyo U, Tokunaga H, Yagi Y, Aoki N, Ogawa M. Extensive intraoperative peritoneal lavage and chemotherapy for gastric cancer patients with peritoneal free cancer cells. Gastric Cancer. 2002;5(3):168-72.

5. Yu XF, Ren ZG, Xue YW, Song HT, Wei YZ, Li CM. D2 lymphadenectomy can disseminate tumor cells into peritoneal cavity in patients with advanced gastric cancer. Neoplasma. 2013;60(2):174-81. 